\title{
Studies in Luke-Acts: Retrospect and Prospect ${ }^{*}$
}

\author{
François Bovon \\ University of Geneva*
}

\section{Introduction}

T et me begin with a personal note. Three experiences in my work on Luke-Acts will explain both the selection of the topics I shall discuss in this article and my view of the present situation in the study of LukeActs.

(1) After ten years of reading the recent studies of Luke-Acts ${ }^{1}$ and then working on the text itself, ${ }^{2}$ I made the observation that the general understanding of the theology of the Gospel of Luke on the basis of its redac-

*An earlier version of this paper was presented to the Luke-Acts Seminar of the Society of Biblical Literature on 25 November 1991 in Kansas City. I would like to thank Professors David Moessner and David L. Tiede for the invitation. I also want to thank my assistants, Isabelle Chappuis-Juillard and Eva Tobler, who helped me during the preparation of this article, as well as Jane Haapiseva-Hunter, who corrected and improved the English of my text.

**François Bovon will join the faculty of Harvard Divinity School as Frothingham Professor of New Testament Studies in the fall of 1993.

${ }^{1}$ François Bovon, Luke the Theologian: Thirty-Three Years of Research (1950-1983) (Princeton Theological Monograph Series 12; Allison Park, PA: Pickwick, 1987) esp. 418.

${ }^{2}$ François Bovon, L'Evangile selon saint Luc $(1,1-9,50)$ (Commentaire du Nouveau Testament 3a; Geneva: Labor et Fides, 1991). 
tional elements was rarely helpful in my effort of writing a commentary on this Gospel. Just as contributors to the more recent volumes of the Theological Dictionary to the New Testament ${ }^{3}$ no longer propose interpretations generally applicable to all three synoptic Gospels, the exegete working with a particular pericope can no longer be satisfied with generalizations about Lukan theology. Indeed, such general assumptions may actually be impediments rather than useful tools for the understanding of a particular text. This is not universally recognized because the attention of scholars has been held by another problem, namely, the substitution of a diachronic redactional interpretation of the Gospels by a synchronic literary interpretation. ${ }^{4}$ The underlying dilemma is, of course, the old question of the connection between exegesis and biblical theology. A promising solution might be to immerse oneself into a single relevant text, as Odette Mainville has done in her recent dissertation on Acts $2: 33,{ }^{5}$ and to obtain universality through the understanding of particularity-in other words, to follow Kierkegaard rather than Hegel.

(2) A growing acquaintance with the Christian apocryphal literature ${ }^{6}$ convinced me that prior to their canonization the Gospels shared both the fortune and the misfortune of the apocryphal literature, namely, a free and rapid reception but an unstable textual transmission. For centuries this remained the fate of the apocryphal materials. An understanding of the life and fate of the Gospels during the second century is decisive for a better knowledge not only of the patristic period, but also of the text of the Gospels themselves. Textual critics of the New Testament can no longer work in isolation from historians of the canon. Everything from codicology to hermeneutics and from historical exegesis to theological interpretation

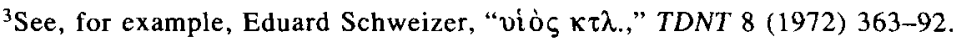

${ }^{4}$ For examples of this approach, see Charles H. Talbert, Reading Luke: A Literary and Theological Commentary on the Third Gospel (New York: Crossroad, 1982); Robert C. Tannehill, The Narrative Unity of Luke-Acts: A Literary Interpretation (Foundations and Facets; 2 vols.; Philadelphia: Fortress, 1986); Roland Meynet, Quelle est donc cette Parole? Lecture "rhétorique" de l'Evangile de Luc (1-9, 22-24) (LD 99; 2 vols.; Paris: Cerf, 1979); idem, L'Evangile selon saint Luc. Analyse rhétorique (2 vols.; Paris: Cerf, 1988); idem, Avez-vous lu saint Luc? Guide pour la rencontre (Lire la Bible 88; Paris: Cerf, 1990); and Jean-Noèl Aletti, $L$ 'art de raconter Jésus-Christ. L'écriture narrative de l'évangile de Luc (Parole de Dieu; Paris: Seuil, 1989).

${ }^{5}$ Odette Mainville, L'Esprit dans l'auvre de Luc (Héritage et Projet 45; Québec: Fides, 1991). An exhaustive analysis of a single verse, Acts $2: 33$, opens the door to a general understanding of the Holy Spirit in Luke-Acts; in turn, this understanding displays the connections with such vital issues as the Hebrew scriptures, christology, and ecclesiology.

${ }^{6}$ Helmut Koester and François Bovon, Genèse de l'écriture chrétienne (Mémoires premières; Turnhout: Brepols, 1991). 
belongs together. Distinctions such as the one between "Primitive Christianity" (Urgemeinde) and "Ancient Church" should be banished, and we should speak of "early Christian literature" as a whole rather than of a specific New Testament literature. Richard Pervo ${ }^{7}$ is correct in reprimanding those who make a firm distinction between the canonical and apocryphal Acts, as if the former were designed to build up the Christian community and the latter to delight the general public. From a New Testament point of view, the quarrel between Marcion and Tertullian over the Gospel of Luke ${ }^{8}$ is extremely relevant. My own picture of the Gospels may be shaken like the second-year undergraduate's image of Christ in a critical course on the Bible. The "historical gospel," like the "historical Jesus," is a vulnerable, this-wordly, conditioned, and enigmatic reality. It is advisable to admit this not only for the sake of our scientific reputation, but also for the sake of our theological position.

(3) Twenty-five years ago, I read with great enthusiasm the diary of Claude Lévi-Strauss, Tristes tropiques, ${ }^{9}$ and planned to publish a study on existential analysis - with which I was quite familiar-and structural analysis—of which I had just become aware. ${ }^{10}$ Since then, I have had many conversations with friends from Lyons (at CADIR: Centre d'Analyse du Discours Religieux) ${ }^{11}$ and from Paris (at CANAL: Centre d'Analyse pour l'histoire du judaïsme hellénistique et des origines chrétiennes de l'Ecole pratique des hautes études, section des Sciences religieuses), as well as with colleagues in the Studiorum Novi Testamenti Societas, where I lead a seminar on linguistics and exegesis together with other scholars. ${ }^{12}$ Although I was convinced that a synchronic view was necessary and that a structural analysis could bring to light the coherence of a biblical pericope or book,

\footnotetext{
${ }^{7}$ Richard Pervo, Profit with Delight: The Literary Genre of the Acts of the Apostles (Philadelphia: Fortress, 1987).

${ }^{8}$ Tertullian Marc. 4.

${ }^{9}$ Claude Lévi-Strauss, Tristes tropiques (Le monde en 10x18, 12-13; Paris: Union Générale d'éditions, 1962).

${ }^{10}$ Roland Barthes, François Bovon, Franz J. Leenhardt, Robert Martin-Archard, and Jean Starobinski, Structural Analysis and Biblical Exegesis: Interpretational Essays (PTMS 3; Pittsburgh: Pickwick, 1974).

${ }^{11}$ See the periodical of CADIR, Sémiotique et Bible, as well as one of their publications, Groupe d'Entrevernes, Signs and Parables: Semiotics and Gospel Texts (PTMS 23; Pittsburgh: Pickwick, 1978).

${ }^{12}$ François Bovon, "Le dépassement de l'esprit historique," in Le Christianisme est-il une religion du livre? Actes du colloque organisé par la Faculté de théologie protestante de l'Université des sciences humaines de Strasbourg du 20 au 23 mai 1981 (Etudes et travaux 5; Strasbourg: Association des publications de la Faculté de théologie protestante et Association de la civilisation romaine, 1984) 111-24.
} 
I was also disturbed by the technocracy of several semiotic procedures, by the methodological dichotomy imposed between genetic and structural explanation of a text, and by the refusal of many semioticians to engage in a resulting discussion of the meaning of the text. Fortunately, these positions, while more pronounced in France, were less prominent in the American scene, where interest in the growth of the text and in hermeneutical issues remained alive. ${ }^{13}$ Structure and genesis, synchrony and diachrony are complementary and should be held together. This was in fact the methodological ideal of the theoreticians of the historical method in its golden age and is expressed particularly in the works of Hermann Gunkel. ${ }^{14}$

\section{The Traditions and Sources Behind Luke-Acts}

During the last two decades, the leading position of the two-source hypothesis has been challenged in several quarters. That the Gospel of Matthew was Luke's source has been vigorously affirmed not only by modern students of Griesbach, ${ }^{15}$ but also by such scholars as Michael D. Goulder. ${ }^{16}$ In his bitter polemic against what he labels "the old paradigm," he develops a new model consisting of eight hypotheses. The following quotation characterizes the model:

Luke wrote his Gospel about 90 for a more Gentile church, combining Matthew and Mark. He re-wrote Matthew's birth narrative with the aid of the Old Testament, and he added new material of his own creation, largely parables, where his genius lay. The new material can almost always be understood as a Lukan development of matter in Matthew. There was hardly any $\mathrm{L}$ (Sondergut). ${ }^{17}$

"Dispensing" with $Q$ (his fourth hypothesis is that " $Q$ is a total error" ${ }^{18}$ ) as well as with L, Luke's special source, Goulder is obliged to assign to Luke a degree of freedom and creativity that is incompatible with the respect for tradition that Luke claims for himself. His last remaining defense to save

\footnotetext{
${ }^{13}$ Edgar V. McKnight, Meaning in Texts: The Historical Shaping of a Narrative Hermeneutics (Philadelphia: Fortress, 1978).

${ }^{14}$ François Bovon, "Hermann Gunkel, Historian and Exegete of Literary Forms," in idem and Grégoire Rouiller, eds., Exegesis: Problems of Method and Exercises in Reading (Genesis 22 and Luke 15) (PTMS 21; Pittsburgh: Pickwick, 1978) 124-42.

${ }^{15}$ William R. Farmer, The Synoptic Problem: A Critical Analysis (2d ed.; Dillsboro, NC: Western North Carolina Press, 1976).

${ }^{16}$ Michael D. Goulder, Luke: A New Paradigm (JSNTSup 20; 2 vols.; Sheffield: Sheffield Academic Press, 1989).

${ }^{17}$ Ibid., 1. 22-23.

${ }^{18}$ Ibid., 1. 22.
} 
the evangelist from arbitrary imagination is the Lukan as well as Matthean respect for liturgy and calendar.

My own attempts to change the paradigm according to the hypothesis of this British scholar were unsuccessful. In the case of one pericope, I tried in my commentary to build the argument on the Griesbach hypothesis. The attempt, however, to imagine how Luke could have modified Matthewwith regard to order as well as style-led into a cul-de-sac. The liveliness of the gospel tradition had to give way to the assumption that a narrowminded author was laboriously copying another's work. Only fancy in the style of Goulder brought some atmosphere of warmth to my laborious and useless attempt. ${ }^{19}$ The history of the origins of Christianity cannot be illuminated by such a paradigm. The weight of the ongoing oral tradition, on the one hand, and the ideological force (from the kerygma as well as from wisdom theology) of the reinterpretation of the Christian message, on the other hand, together suggest a different approach to the understanding of Luke, who stands at the crossroads of the synoptic tradition and the Pauline mission.

French criticism has proposed two extreme solutions to the synoptic problem. The most complex is that of Marie-Emile Boismard, ${ }^{20}$ who constructs many intermediate steps, while that of Philippe Rolland ${ }^{21}$ is quite simple. Rolland's efforts are commendable insofar as he attempts to integrate the main first-century Christian churches-Jerusalem, Antioch, Caesarea, Romeinto the history of the synoptic tradition. He further believes that the traditional elements-creeds and gospels of the several churches-were definitely maintained in the further developments. According to his theory, the tradition began with the primitive (oral) gospel of the Twelve in Jerusalem. This gospel experienced a double reception: in Antioch in a pre-Matthean form as the gospel of the Hellenists, and in Ephesus or Philippi-that is, in the Pauline school-in a pre-Lukan form. While Matthew then developed, using additional ingredients, the Hellenist form of the Gospel, Luke received and amplified the Pauline form, also adding new elements. Some of these new elements are common to both (two forms of $Q$, which he believes to be the gospel of those "Fearing God"), other proper to each of the two evangelists

${ }^{19}$ I was not entirely convinced by C. M. Tuckett, ed., Synoptic Studies: The Ampleforth Conferences of 1982 and 1983 (JSNTSup 7; Sheffield: JSOT Press, 1984), and particularly by the article by H. Benedict Green "The Credibility of Luke's Transformation of Matthew" (pp. 131-55) in that volume.

${ }^{20}$ Marie-Emile Boismard, Arnaud Lamouille, and P. Sandevoir, Synopse des quatre Évangiles en français, vol. 2: Commentaire (Paris: Cerf, 1972).

${ }^{21}$ Philippe Rolland, Les premiers évangiles. Un nouveau regard sur le problème synoptique (LD 116; Paris: Cerf, 1984). 
(Sondergut). Matthew and Luke, then, are not dependent upon Mark's Gospel, which is seen as a conflation of the two preliminary forms, the preMatthean and the pre-Lukan Gospel. Mark is a witness of the church in Rome, Matthew of the church in Antioch, and Luke belongs to the missionary team of Paul.

I remain attached, perhaps stubbornly, to the two-source hypothesis. But I also agree with Helmut Koester, ${ }^{22}$ who emphasizes the vital corollary of an oral tradition that was thoroughly reformulated in view of changing congregational interests. This implies my rejection of the thesis of Birger Gerhardsson, ${ }^{23}$ who understands the gospel tradition in terms of a strict rabbinic-type transmission. My study of the unpredictable and unstable life of apocryphal traditions made me aware of the flexible trajectories to which synoptic stories or speeches were subject. The discovery of the Gospel of Thomas as well as the elegant solution of the problem of the "minor agreements" by reference to an ongoing oral tradition alongside already existing written documents (compare Sigmund Mowinckel's explanation for the existence of the Elohist in the Hebrew Bible ${ }^{24}$ ) confirms this opinion. ${ }^{25}$

$\mathrm{Q}$ and $\mathrm{L}$, the synoptic sayings source and the source of the Lukan special materials, are no longer just possible, but rather fruitful and productive hypotheses. The lively interest in $\mathrm{Q}$, understood as both sapiential and apocalyptic, is fascinating. If the first volume of my commentary owes much to the older works on Q by Dieter Lührmann, Paul Hoffmann, and Heinz Schürmann, ${ }^{26}$ the second volume is heavily indebted to the dozen books written on $Q$ during the last ten years, particularly that of John Kloppenborg and the volume from the Journées Bibliques entitled Logia, ${ }^{27}$

\footnotetext{
${ }^{22}$ Helmut Koester, Ancient Christian Gospels: Their History and Development (Philadelphia: Trinity, 1990) 334-36; François Bovon, L'Evangile selon saint Luc, 27-29.

${ }^{23}$ Birger Gerhardsson, Memory and Manuscript: Oral Tradition and Written Transmission in Rabbinic Judaism and Early Christianity (ASNU 22; Lund: Gleerup, 1961).

${ }^{24}$ Sigmund Mowinckel, Erwägungen zur Pentateuchquellenfrage (Oslo: Universitetsforlaget, 1964).

${ }^{25}$ See Helmut Koester, Ancient Christian Gospels, 75-128; Timothy A. Friedrichsen, "The Matthew-Luke Agreements Against Mark," in F. Neirynck, ed., L'Évangile du Luc: The Gospel of Luke (BETL 32; 2d ed.; Leuven: Leuven University Press and Peeters, 1989) 335-92.

${ }^{26}$ Dieter Luhrmann, Die Redaktion der Logienquelle. Anhang: Zur weiteren Überlieferung der Logienquelle (WMANT 33; Neukirchen-Vluyn: Neukirchener Verlag, 1969); Paul Hoffmann, Studien zur Theologie der Logienquelle (NTAbh n.s. 8; 3d ed.; Münster: Aschendorff, 1982); Heinz Schürmann, Traditionsgeschichtliche Untersuchungen zu den synoptischen Evangelien. Beiträge (Kommentare und Beiträge zum Alten und Neuen Testament; Düsseldorf: Patmos, 1968).

${ }^{27}$ John S. Kloppenborg, The Formation of Q: Trajectories in Ancient Wisdom Collections (Studies in Antiquity and Christianity; Philadelphia: Fortress, 1987); Ronald A. Piper, Wis-
} 
not to mention the recent commentary on the special materials (L) of Luke by Gerd Petzke. ${ }^{28}$ In a closing chapter, following the commentary on $\mathrm{L}$ itself, Petzke presents an original and instructive summary of the primary emphases (Schwerpunkte) of L: the artistic method of good storytelling, present in $\mathrm{L}$ as well as in Luke; the function of the parables, which invite the readers to identify themselves with the world of the narrative; the portrait of a half-historical and half-mythological Jesus. ${ }^{29}$ The book concludes with a discussion of Jesus' interest in the individual, as well as an exposition of several topics of Lukan theology.

\section{The Text of Luke-Acts}

With great modesty-his name does not appear on the title page-executive editor J. K. Elliott has produced two volumes with the text of the Gospel entitled The Gospel According to Luke. ${ }^{30}$ It is important to specify that these two volumes, the fruit of an old project of the American and British Committees of the International Greek New Testament Project, are not a new critical edition of the Greek text. Rather, the printed text is nothing other than the old textus receptus, but it has received a full critical apparatus. For each verse one will find, following the textus receptus, a list of the defective manuscripts, a list of quotations of the verse by the Fathers (a unique and formidable source of information), and a full apparatus of the Greek, Latin, and Syriac New Testament manuscripts. The information is presented in an easily readable format, and many valuable observations can be made. For example, for Luke 11:2, the beginning of the Lord's Prayer, the famous reading, "Your Spirit come upon us and purify us" (minuscule 700 and Gregory of Nyssa Homiliae in orationem dominicam 3.737-38) is presented well. Unfortunately, the quotation of this strange reading by

dom in the Q-tradition: The Aphoristic Teaching of Jesus (SNSTMS 61; Cambridge: Cambridge University Press, 1989); Migaku Sato, $Q$ und Prophetie, Studien zur Gattungs- und Traditionsgeschichte der Quelle $Q$ (WUNT 2, Reihe 29; Tübingen: Mohr, 1988); Dieter Zeller, Kommentar zur Logienquelle (Stuttgarter Kleiner Kommentar, Neues Testament 21; Stuttgart: Katholisches Bibelwerk, 1984); Joël Delobel, ed., Logia, Les paroles de Jésus-The Sayings of Jesus, Mémorial J. Coppens (BETL 49; Leuven: Leuven University Press, 1982).

${ }^{28}$ Gerd Petzke, Das Sondergut des Evangeliums nach Lukas (Zürcher Werkkommentare zur Bibel; Zürich: Theologischer Verlag, 1990).

${ }^{29}$ Petzke (ibid., 235-41) explains well how one should deal with myths in a scientific century through Entmythologisierung and Remythisierung, in dialogue with Rudolf Bultmann, on the one side, and Eugen Drewermann, on the other.

${ }^{30}$ The Gospel According to St. Luke (The New Testament in Greek 3; ed. American and British Committees of the International Greek New Testament Project; 2 vols.; Oxford: Clarendon, 1984-1987). 
Maximus the Confessor (not Maximus of Turin, as Bruce M. Metzger ${ }^{31}$ wrongly assumes) is not mentioned. Why not? Presumably because this church father lived after the chronological deadline $(500 \mathrm{CE})$. Another feature of this edition is that the apparatus, for practical reasons, is negativea permanent source of mistakes for the author and for the user! In spite of these limitations, the two volumes are a welcome tool, a handy and comprehensive view of the manuscript evidence for the Gospel of Luke.

In recent years, sympathy for the western text of Luke and Acts has been growing in France. In the new edition of the introduction to textual criticism by Léon Vaganay, Christian-Bernard Amphoux has made a good case for this form of the Lukan text. ${ }^{32}$ At the same time, Marie-Emile Boismard and Arnaud Lamouille on the one side, ${ }^{33}$ and the late Edouard Delebecque on the other, ${ }^{34}$ came to the conviction that the two recensions of the Acts of the Apostles are equally venerable and equally Lukan. These French scholars are convinced that the so-called western readings of Acts bear marks of genuine Lukan style. But the discovery of Papyrus Bodmer XIV-XV $\left(P^{75}\right)$, the oldest witness for the Gospel of Luke, has established the great age and value of the Egyptian text. ${ }^{35}$ Therefore, only two solutions remain for supporters of the western text: either the two texts are both witnesses of a lost original (the theory of Boismard and Lamouille) or Luke himself produced two editions of Luke-Acts (the strange hypothesis of Delebecque). This latter theory is not new; it was already proposed by Friedrich Blass. ${ }^{36}$ In contrast to Blass, however, Delebecque believes that the western text is an amplification by Luke himself (!) of the text preserved in the Egyptian tradition.

In his defense of the western text, Christian-Bernard Amphoux goes even further and places it in the primary position:

\footnotetext{
${ }^{31}$ Bruce M. Metzger, A Textual Commentary on the Greek New Testament (London/New York: United Bible Societies, 1971) 155.

${ }^{32}$ Léon Vaganay and Christian-Bernard Amphoux, Initiation à la critique textuelle du Nouveau Testament (2d ed.; Paris, Cerf, 1986); ET: An Introduction to New Testament Textual Criticism (trans. Jenny Heimerdinger; Cambridge: Cambridge University Press, 1991).

${ }^{33}$ Marie-Emile Boismard and Arnaud Lamouille, Le texte occidental des Actes. Reconstitution et réhabilitation (Synthèse 17; 2 vols.; Paris: Editions Recherche sur les Civilisations, 1984). Since 1984 these authors have published a large commentary on the Book of Acts: idem, Les Actes des deux apôtres (ÉtBib n.s.12-14; 3 vols.; Paris: Gabalda, 1990).

${ }^{34}$ Edouard Delebecque, Les deux Actes des apôtres (ÉtBib n.s. 6; Paris: Gabalda, 1986).

${ }^{35}$ Victor Martin and Rodolphe Kasser, Papyrus Bodmer XIV-XV, Évangile de Luc et de Jean, $P^{75}$ (2 vols.; Cologne/Geneva: Bibliotheca Bodmeriana, 1961).

${ }^{36}$ Friedrich Blass, Acta apostolorum, sive Lucae ad Theophilum liber alter, editio philologica (Göttingen: Vandenhoeck \& Ruprecht, 1895).
} 
On the basis of this hypothesis, those who, following von Soden's exceptional insights, have upheld the primitive character of the "Western" text have, by their persistence in the face of opposition and technical difficulties, been the pioneers of what could be, in the not too distant future, a radical new conception of first-century Christianity. ${ }^{37}$

I remain rather skeptical with respect to such hypotheses. I still prefer the shorter Egyptian text and cannot believe in a double edition of LukeActs written by Luke himself. However, I admire the originality of Amphoux's research. Using Luke 5 as a test case, he attempts to reconstruct the history of the text from the first to the second century. He believes that Papias's knowledge of the Gospel tradition and the responsibility assigned to Polycarp by Ignatius favor a first edition of the four Gospels in the first quarter of the second century. The text of this edition would be similar to the longer western text. Only later, after the disillusionment of the Bar Kokhba rebellion, did the church's theological schools-first in Rome and then in Alexandria-prepare a second edition of the New Testament. According to Amphoux, the successful text of this revised edition is the Egyptian text of about $175 \mathrm{CE}^{38}$

\section{The Structure of Luke's Gospel}

A new kind of Lukan study-rhetorical, structural, or literary interpretation-has emerged as a result of two complementary causes. The first cause is the gradual increase of skepticism facing the historical-critical method, particularly the two-source hypothesis and the excesses of redaction criticism. The second cause is the growing interest in literary interpretation in the fields of English and French literature. In this new approach, each Gospel is not primarily the result of the composition of traditional materials, actualized by a historical author confronting a particular ecclesiastical or existential situation; rather, it is "an intricately designed religious universe, with plot and character development, retrospective and prospective devices, linear and concentric patterning, and a continuous line of thematic cross-references and narrative interlockings."39

I know of five new commentaries or interpretations along these lines, two in English and three in French. Charles H. Talbert ${ }^{40}$ combines a liter-

${ }^{37}$ Vaganay and Amphoux, Introduction, 171.

${ }^{38}$ Christian-Bernard Amphoux, "Les premières éditions de Luc, I, Le texte de Luc 5," EThL 67 (1991) 312-27; idem, "Les premières éditions de Luc, II, L'histoire du texte au II siècle," EThL 68 (1992) 38-48.

${ }^{39}$ Werner Kelber, "Redaction Criticism: On the Nature and Exposition of the Gospels," Perspectives in Religious Studies 6 (1979) 14, quoted in Talbert, Reading Luke, 2.

${ }^{40}$ Talbert, Reading Luke. 
ary view with a socio-cultural approach: the literary structure and function of the twofold work of Luke are dependent on the historical situation of Christianity at the end of the first century. In his view, such a narrative in two parts-one devoted to the founder of a new religious movement, the other devoted to his successors-had a legitimizing function in antiquity: "This narrative of Jesus and the early Church is a legitimation document: its story is told with a persuasiveness intended to give certainty."41 Three elements support this purpose of the work: (1) the story of the martyrdom of the hero; (2) the stories of his great works, namely, his miracles; (3) the memory of the prophecies or oracles, which are now fulfilled in the life of the founder of the religious or philosophical movement. It is not always easy, however, to see the connection between these propositions ${ }^{42}$ and the shape of the literary interpretation. Talbert no longer divides Luke's Gospel into three parts, as Hans Conzelmann did, ${ }^{43}$ but into four: "Prophecies of future greatness" (1:5-4:15); "Anointed with the Holy Spirit" (4:16-9:50); "Guidance on the Way" (9:51-19:44); "Martyrdom and vindication" (19:4524:53).

The exegetical sensitivity of Robert C. Tannehill ${ }^{44}$ is well known. From his new perspective, theological insights are no longer gained through synoptic comparison and genetic explanation (redaction versus tradition) but, in his own words, by detecting "disclosures" that Luke "has carefully provided," "disclosures of the over-arching purpose which unifies the narrative." The "literary clues show the importance of these disclosures."45 "On the borderline between character and plot," 46 Tannehill reads a story emerging "as a dialogue between God and a recalcitrant humanity." 47 Lukan literary devices are parallelisms, internal connections, progressive sequences, and repetitions.

Such French scholars as Roland Meynet, Charles L'Eplattenier, and Jean Noël Aletti are driven by the same forces that Tannehill and Talbert are. Searching for a similar general coherence, they have used the tools of ancient rhetoric (Meynet) or narratology (Aletti).

${ }^{41}$ Ibid., 5 .

${ }^{42}$ One of these propositions has been criticized; it does not seem that a genre has existed with (1) the life of the founder, and (2) the story of his successors. See David L. Balch, "The Genre of Luke-Acts: Individual Biography, Adventure Novel, or Political History?" Southwestern Journal of Theology 33 (1990) 5-6.

${ }^{43}$ Hans Conzelmann, Die Mitte der Zeit, Studien zur Theologie des Lukas (2d ed.; BHTh 17; Tübingen: Mohr/Siebeck, 1962).

${ }^{44}$ Tannehill, The Narrative Unity of Luke-Acts.

${ }^{45}$ Ibid., 1, 1.

${ }^{46}$ Ibid.

${ }^{47}$ Ibid., 1. 2. 
As a student of Georges Mounin, Meynet received a good education in linguistics. ${ }^{48} \mathrm{He}$ contrasts Hebraic and Greek rhetoric and elaborates the Jewish rules of story-writing: what corresponds to the Greek dispositio is a coherent appeal to special figures, parallelisms, chiasms, repetitions, inclusions, and so on. What has been wrongly labeled the episodic style of Luke is actually a series of sequences constituting an organic literary composition of these very figures. Like Talbert, he sees in the Gospel a story in four stages: the coming of Jesus, prepared by John (1:5-4:13); the call of the disciples in Galilee (4:14-9:50); the progression of Jesus and his disciples to Jerusalem (9:51-21:38-note this late break); and what he calls the Passover of Jesus the Christ (22:1-24:53). ${ }^{49}$ In his latest work, ${ }^{50}$ Meynet, after dividing the four stages mentioned above into a total of twenty-eight sequences, places two sequences at the heart of the Gospel: the last sequence of stage two (9:1-50: the disciples called to do what Jesus does), and the first sequence of stage three (9:51-10:42: the departure to the Passion). Even if Meynet remains cautious, he has the unfortunate tendency to see concentric structures everywhere-the triumph of the chiasm in the Hebrew narrative structure.

My two objections to these works concern their structural divisions and the paraphrastic character of their interpretation. For example, if one compares Meynet and Talbert on the beginning of the travel narrative (9:51ff.), one discovers two completely different divisions of the text, although both presuppose the presence of a chiasm at this point. For Talbert, ${ }^{51}$ 9:51-10:24 forms a concentric unity: $9: 51-56=A ; 10: 1-24=A^{1}$; and $9: 57-62=B . A$ and $A^{l}$ point to the Lukan theology of the word (mission and missionary behavior), $A$ to the future Christian mission in Samaria and $A^{l}$ to the mission to the Gentiles; $B$ points to the costs of discipleship. For Meynet, ${ }^{52}$ there is a much larger chiasm: $9: 51-56$ corresponds to $10: 38-42$ and is determined by the notion of departure; 9:57-10:11 is determined by the announcement of the kingdom of God and human free will in the light of this announcement. An example of paraphrastic interpretation appears in Tannehill's comments on the story of the Feeding of the Five Thousand: (a) the Twelve have a prominent role in the story, (b) the narrative "focusses on the interaction between Jesus and the twelve," (c) the excess of food "suggests that the apostles are abundantly supplied for their future mission."53

\footnotetext{
${ }^{48}$ See Meynet's first work, Quelle est donc cette Parole? 1. 11-19.

${ }^{49}$ Meynet, L'Evangile selon saint Luc.

${ }^{50}$ Meynet, Avez-vous lu saint Luc?

${ }^{51}$ Talbert, Reading Luke, 114-19.

${ }^{52}$ Meynet, Avez-vous lu saint Luc? 32-37.

${ }^{53}$ Tannehill, The Narrative Unity of Luke-Acts, 216-17.
} 
A positive aspect of the work of literary interpreters, in spite of their reluctance to use source criticism, is the fact that they are quite open to the exploration of intertextuality. This is true particularly with respect to the relationship of the Gospels to parallels and to analogous stories in Hebrew scripture, as, for example, in the case of the relationship of the feeding of the five thousand to the cycle of the stories of Elijah (1 Kings 17) and Elisha (2 Kgs 4:42-44). ${ }^{54}$

\section{Luke and Judaism}

I was surprised by the recent lively debate stemming from the discussion between Jacob Jervell and the exegetical consensus. For most exegetes, Luke is a Gentile trying to legitimate a gentile Christianity that is free from the law, yet related to scripture. For Jervell, however, the theological perspective of Luke-Acts is rooted not in the failure of the Christian mission to the Jews, but in its success. ${ }^{55}$

In the $1980 \mathrm{~s}$, attention focused quite unexpectedly on the way in which Luke shows a positive appreciation for the Jewish people, the Jewish law, and the Jewish temple. Two phenomena may help to explain this sparking of interest: first, the more general debate about the relationship of Judaism and Christianity after the Holocaust; and second, the introduction of sociological methods into the field of New Testament scholarship. The first phenomenon raises theological reflection on the question of the law. Is the Jewish law still relevant for Luke? If so, in what sense? The second phenomenon requires some thought about the social situation of Luke and of his audience. As a consequence, many interpreters today think that Luke himself was a Jew and that his main interest was Israel rather than the gentile mission. Is this assumption correct?

While theology was the starting point in the $1960 \mathrm{~s},{ }^{56}$ it now appears to be an implication of a particular socio-cultural reading. To use Jean-Paul Sartre's definition of freedom, Luke is determined by his personal social background and is not free to reject these determinants ("The main point is not what has been done to the human being, but what he does about what has been done to him"). ${ }^{57}$ I have chosen several divergent positions to illustrate the recent discussion.

\footnotetext{
${ }^{54}$ See the appendix below for a discussion of the work of Jean-Noël Aletti.

${ }^{55} \mathrm{Jacob}$ Jervell, Luke and the People of God: A New Look at Luke-Acts (Minneapolis: Augsburg, 1984). For my own opinion on this position, see Bovon, Luke the Theologian, 334-39.

${ }^{56}$ Bovon, Luke the Theologian, 323-39.

57 “Jean-Paul Sartre répond," L'Arc 30 (1966) 95.
} 
Robert L. Brawley ${ }^{58}$ tries to break the conventional pattern. For him, Luke 4:16-30 is not an example showing that the Gospel was rejected by the Jews and was therefore passed on to the Gentiles. Rather, it is a piece of literature that was meant to designate the identity of Jesus. Similarly, the second half of Acts is not a long description of a Christian church that has cut the lines by which it was anchored in Judaism, but simply a description of the Pauline mission:

Therefore, the standard paradigm for understanding Luke's view of the relation between Christianity and Judaism should pivot 180 degrees. That is, rather than setting Gentile Christianity free, Luke ties it to Judaism. And rather than rejecting the Jews, Luke appeals to them. ${ }^{59}$

Luke does not reject the non-Christian Jews but offers reconciliation with them.

As is well known, the position of Jack T. Sanders ${ }^{60}$ is completely different. He refuses to delete the anti-Jewish traits of Luke-Acts:

In my own contribution to the debate, I examined the way in which the author of Luke-Acts presented the Jewish leaders, Jerusalem, the Jewish people, the Pharisees, and what I chose to call the periphery, Samaritans, proselytes, and God-fearers. I concluded, among other things, that Haenchen was essentially correct, that the author of LukeActs does view the Jewish people generally as opposed to the purposes of God, as unable to understand their own scriptures, and as both foreordained to reject and wilfully rejecting their own salvation. ${ }^{61}$

Sanders's main aim is to investigate the reason for this theological attitude. In his opinion, it is not a Jewish persecution that motivated the negative judgment on the part of Luke, but intellectual and practical Jewish opposition to the Christian message. Having established this understanding of Luke - correct, in my view-Sanders continues to condemn Luke, accusing him of an anti-Judaism as stark as that of the Gospel of John.

The doctoral dissertation of Matthias Klinghard ${ }^{62}$ is a very insightful work, but difficult to read. He begins with questions about Luke's under-

\footnotetext{
${ }^{58}$ Robert L. Brawley, Luke-Acts and the Jews: Conflict, Apology, and Conciliation (SBLMS 33; Atlanta: Scholars Press, 1987).

${ }^{59}$ Ibid., 159.

${ }^{60}$ Jack T. Sanders, The Jews in Luke-Acts (London: SCM, 1987); idem, "The Jewish People in Luke-Acts," in Joseph B. Tyson, ed., Luke-Acts and the Jewish People: Eight Critical Perspectives (Minneapolis: Augsburg, 1988) 51-75; idem, "Who Is a Jew and Who Is a Gentile in the Book of Acts?" NTS 37 (1991) 434-55.

${ }^{61}$ Sanders, "Who Is a Jew," 436.

${ }^{62}$ Matthias Klinghardt, Das lukanische Verständnis des Gesetzes nach Herkunft, Funktion und seinem Ort in der Geschichte der Urchristentums (WUNT 2, Reihe 3; Tübingen: Mohr/
} 
standing of the content and function of the Mosaic law. With regard to the content, he arrives at a fine and subtle solution. Luke's reading of the law underlines rules of purity and the renunciation of wealth (see Luke 16). The Apostolic Decree (Acts 15:28-29) states that the Gentiles must also follow some rules of purity, and the Gospel of Luke shows that a wealthy Jewish Christian is subject to the moral law of poverty. Henceforth, voluntary poverty becomes a necessary legal condition for obtaining salvation (the polemic against the Pharisees is so bitter because they impose only external purity requirements but no internal moral conditions). In contradistinction to Paul, Luke is not replacing salvation through works with salvation through faith, but rather salvation through ritual works with salvation through Christ and moral works. The required obedience has not only a soteriological function, but also an ecclesiological component: it brings the convert into the company of the real people of God. According to Klinghardt, the gentile Christians are the poor in the Lukan congregation while the Jewish Christians are the rich. Luke tries to convince these rich Jewish Christians to accept the poor gentile converts as brothers and sisters.

In an analysis of Acts 13:38-39 and 15:10-11, Klinghardt demonstrates that Luke is arguing on an ecclesiological as well as on a soteriological level. One of the important functions of the law is to determine who belongs to the true Israel. This implies that the law has not been abolished. These verses should not be understood, as they usually are, against the background of Pauline theology. The Lukan community is mixed and includes a strong Jewish-Christian element. In this community, obedience to the law and union with Christ belong together, just as the Decalogue and the commandment of love (Luke 10:25-37) form a unity.

The works of Kalervo Salo ${ }^{63}$ and Philip F. Esler ${ }^{64}$ also deserve attention. Salo finds that Luke's interest in the law is practical rather than theological. The Jewish Christians are invited to maintain a formal obedience to the law, while the gentile Christians are liberated from its burden. For the former, one can speak of a covenant nomos, but for the latter only of a covenant. Esler's approach is determined more by a socio-cultural than by a theological perspective. What motivates Luke is both his community's critical discussion with Judaism and its strong crisis of identity. Three factors are pertinent: the converts' former religious affiliations (ranging from

\footnotetext{
Siebeck, 1988).

${ }^{63}$ Kalervo Salo, Luke's Treatment of the Law: A Redaction-Critical Investigation (Annales Academiae Scientiarum Fennicae, Dissertationes humanarum litterarum 57; Helsinki: Suomalainen Tiedeakatemia, 1991).

${ }^{64}$ Philip F. Esler, Community and Gospel in Luke-Acts: The Social and Political Motivations of Lucan Theology (SNTSMS 57; Cambridge: Cambridge University Press, 1987).
} 
pagan idolatry to Jewish conservatism); their economic situation (including the highest as well as the lowest strata of the economic spectrum); their political positions (ranging from submission to Rome to a determination to fight for independence). Luke freely reshapes the gospel tradition for a practical response to the needs of his fellow Christians. Luke-Acts may thus be described as an exercise in legitimating a sectarian movement.

To conclude this section, I would add some personal comments. First, among the books of the New Testament Luke-Acts is the text that is both the most open to universalism and the most favorable to Israel. Luke describes the Jewish roots of the church and the universal geographical expansion of the gospel with equal affection. Second, it is unfortunate that in the heat of the present discussion and its polemic there is a tendency to forget the previous discussion. The names of Frank Stagg, Philippe Menoud, Jacques Dupont, J. C. O'Neill, Joachim Gnilka, Augustin George, Stephen G. Wilson, and Paul Zingg, scholars who wrote in the 1960s and 1970s, rarely appear. ${ }^{65}$

Third, to a greater degree than many recent writers, I would emphasize the discontinuity between Israel and the church. The ideological defense of the universalism that is visible throughout the Gospel of Luke and the Acts of the Apostles ${ }^{66}$ appears to me to be the religious counterpart of Roman imperial ambitions. Luke's description of the Christian communities in their confrontation with the Judaic world is, from the sociological point of view and in the terminology of Ernst Troeltsch, a testimony of a sectarian identity. The situation of Christianity in the time of Luke is not yet that of early catholicism. Summing up his entire work in Acts 28:26-27, Luke quotes Isa 6:9-10. One cannot be blind with respect to the function of this last quotation, especially in the light of its introduction and interpretation (Acts 28:25, 28). The introduction underlines the consensus between the Hebrew prophet Isaiah and the Christian preacher Paul, both inspired by the spirit of God and both contrasted with the Jewish leaders, whose discord Luke mentions explicitly (Acts 28:25: "they disagreed with each other"). The interpretation of the quotation from Isaiah asserts: "Let it be known to you then that this salvation of God has been sent to the Gentiles; they will listen" (Acts 28:28). There remains only one uncertainty: Is there a slight hope for the salvation of Israel expressed in the last phrase of the quotation, if one can read it in the future tense, "and I shall heal them"? I would

\footnotetext{
${ }^{65}$ The studies of all these scholars, as well as those of Hans Conzelmann, Ernst Haenchen, and Jacob Jervell are discussed in Bovon, Luke the Theologian, 323-43.

${ }^{66}$ François Bovon, "Israel, die Kirche und die Völker im lukanischen Doppelwerk," $T h L Z$ 108 (1983) cols. 403-14.
} 
answer this question positively. Luke is then indeed a pupil, albeit an indirect pupil, of Paul (compare Rom 11:25-36). ${ }^{67}$

Finally, salvation is offered by God, who showed a continuing love during the entire life and ministry of Jesus. Jesus' words (see Luke 6:47) are the actual revelation of the will of God and the eschatological and spirit-empowered interpretation of the law. Like the prophetic scriptures, the law maintains the dual function of testifying to the future of the divine economy of salvation and of preparing the expression of the new obedience (see the twofold commandment of love). However, conversion is more important than obedience, because it is the way to God for human beings; the way of God to human salvation is found throughout the entire life of Jesus and in his resurrection. ${ }^{68}$

\section{- The Theology of Luke}

Luke is a good storyteller, pleasant to read and easy to understand. It is more difficult to grasp what he believes and why he writes. As a theologian, he is an enigmatic figure. This explains the great variety of keys used to understand his theology.

In the 1950s, Philipp Vielhauer and Hans Conzelmann presented Luke as a creative mind and a theologian of history who was able to rethink eschatology in terms of the history of salvation. ${ }^{69}$ Twenty years later, due to the intellectual force of the works of such Roman Catholic theologians as Heinz Schürmann, Joseph Ernst, Gerhard Schneider, Augustin George, and Joseph Fitzmyer, the Third Evangelist developed a much more pastoral character. ${ }^{70}$ The main theological weight was placed no longer upon the

\footnotetext{
${ }^{67}$ François Bovon, "'Schón hat der heilige Geist durch den Propheten Jesaja zu euren Vätern gesprochen' (Apg 28,25)," ZNW 75 (1984) 345-50.

${ }^{68}$ On the topic of Luke and Judaism see also Lawrence M. Wills, "The Depiction of the Jews in Acts," JBL 110 (1991) 631-54; and David A. Neale, None but the Sinners: Religious Categories in Gospel of Luke (JSNTSup 58; Sheffield: Sheffield Academic Press, 1991). That Jesus is for the sinners and against the Pharisees is, according to Neale, not a historical memory but an ideological interpretation. On Luke's view of the temple, see Bovon, L'Evangile selon saint Luc, 139 n. 28 (with bibliography).

${ }^{69}$ Philipp Vielhauer, "Zum 'Paulinismus' der Apostelgeschichte," EvTh 10 (1950-1951) 1-15, reprinted as idem, Aufsätze zum Neuen Testament (ThBü 31; Munich: Kaiser, 1965) 927; Conzelmann, Die Mitte der Zeit.

${ }^{70}$ Heinz Schürmann, Das Lukasevangelium I (HThKNT 3; Freiburg; Herder, 1969); Joseph Ernst, Das Evangelium nach Lukas übersetzt und erklärt (RNT; Regensburg: Pustet, 1977); Augustin George, Etudes sur l' æuvre de Luc (SB; Paris: Gabalda, 1978); Gerhard Schneider, Das Evangelium nach Lukas (Oekumenischer Taschenbuch-Kommentar zum Neuen Testament 3.1-2; 2d ed.; 2 vols.; Gütersloh: Gütersloh Verlagshaus and Würzburg: Echter Verlag, 1984); Joseph A. Fitzmyer, The Gospel According to Luke (AB 28-28A; 2 vols.; New York: Doubleday, 1981-1985).
} 
view of the end of the time, but on the time of the church-a time that was not much separated from the time of Christ's life. In the numerous books and articles published by Jacques Dupont, ${ }^{71}$ the Lukan Christ occupies center stage. Not merely the cross or the teaching or the resurrection, but the whole course of his life from the birth to the ascension is the focus of attention. ${ }^{72}$ I am quite comfortable with this christological understanding of Luke's work, and I am trying to connect it with the Lukan theology of the word of God and its necessary human and historical mediation. Of course, Lukan theology does not emphasize knowing Christ per se, his nature and his metaphysical identity, but-to use Philipp Melanchthon's definition"his benefactions." Several scholars, such as Robert F. O'Toole and Robert J. Karris, ${ }^{73}$ have insisted upon this soteriological accent to Luke's theology.

No general agreement has been achieved about Luke's theology during the last decade, but a number of specific tendencies can be identified.

(1) Constantly recurring is the emphasis upon Luke's ethics (many state that Luke is a pragmatic thinker), particularly on the ethics of money (Luise Schottroff and Wolfgang Stegemann ${ }^{74}$ ) or, more recently, on the ethics of loving one's enemies (Josephine Massyngbaerde Ford ${ }^{75}$ ).

(2) More original is the theological consideration of the Lukan stories, which are no longer read as holy scripture but as mythopoeic art. Eugen Drewermann ${ }^{76}$ presents a Jungian type of psychoanalytic understanding of the birth stories. From a post-Bultmannian perspective Gerd Petzke ${ }^{77}$ reads Luke and his special materials in a dialectic of demythologizing mythological statements and mythologizing historical events; this is presented in a polemical dialogue with an over-scientific modern conception of reality.

\footnotetext{
${ }^{71}$ A bibliography of Dupont's works can be found in A cause de l'Evangile: Études sur les Synoptiques et les Actes offertes au P. Jacques Dupont $O$. S. B à l'occasion de son $70 e$ anniversaire (LD 123; Paris: Cerf and Bruges: Saint-André, 1985) 809-26.

${ }^{72}$ Emmeram Kränkl, Jesus, der Knecht Gottes: Die heilsgeschichtliche Stellung Jesu in den Reden der Apostelgeschichte (Biblische Untersuchungen 8; Regensburg: Pustet, 1972); Gerhard Lohfink, Die Himmelfahrt Jesu: Untersuchungen zu den Himmelfahrts-und Erhöhungstexten bei Lukas (SANT 26; Munich: Kösel, 1971).

${ }^{73}$ Robert F. O'Toole, The Unity of Luke's Theology: An Analysis of Luke-Acts (Good News Studies 9; Wilmington, DE: Glazier, 1984); Robert J. Karris, Luke: Artist and Theologian: Luke's Passion Account as Literature (Theological Inquiries; New York: Paulist, 1985).

${ }^{74}$ Luise Schottroff and Wolfgang Stegemann, Jesus von Nazareth: Hoffnung der Armen (Urban Taschenbücher 639; 2d ed.; Stuttgart: Kohlhammer, 1981).

${ }^{75}$ Josephine Massyngbaerde Ford, My Enemy is My Guest: Jesus and Violence in Luke (New York: Crossroad, 1984).

${ }^{76}$ Eugen Drewermann, Dein Name ist wie der Geschmack des Lebens: Tiefenpsychologische Deutung der Kindheitgeschichte nach dem Lukasevangelium (Freiburg: Herder, 1986).

${ }^{77}$ See above n. 28.
} 
(3) It is strange that during the years of the heated debate about Lukan salvation history there was no consideration of Luke's theology in the narrower sense, namely, as doctrine about God. Following Jacques Dupont's complaint about this omission, Karl Erlemann ${ }^{78}$ investigated the Lukan description of God through an analysis of the metaphors, parables, and references to the Hebrew scriptures. According to Erlemann's investigation, Luke's God is more the Lord than the Judge. It is in God's function as the Lord that God will rescue and save. While respecting the freedom of human beings, he rejoices when his people accept the offer of salvation. As Mammon is the negative counterpart of God, it is logical that the renunciation of possessions becomes the corollary of faith in Christ the Lord. The image of God also has an integrative force in its ecclesiological function.

(4) What could be called a typological reading of Luke, or an understanding of his work in light of the Hebrew Bible, follows the line of patristic interpretation. David P. Moessner, in his important book, analyzes the Lukan travel narrative and arrives at the conclusion that Luke saw this decisive step in the career of Jesus as a counterpart and antitype of the founding event of Israel, namely, the Exodus of the people from Egypt to the Promised Land. According to this perspective, Jesus is seen as the last prophet, indeed as a prophet like Moses (Deut 18:15, 18), that is, the rejected messenger of God from the Deuteronomistic tradition. As a consequence, Israel is seen as the "stiff-necked people": "Luke's central section is the story of the journeying salvation of the new Exodus prophesied by Moses to the people of the Horeb covenant as the fulfillment of the promises to Abraham and his descendants."79

\section{The First Reception of the Gospel of Luke}

The history of interpretation is a relatively young discipline. Historians found the historical investigations of the exegetes too theological; exegetes were disappointed by the results of the historians because of the lack of theological relevance. In the guild of New Testament scholars, the history of interpretation is often perceived as an interesting cultural addition, but not an indispensible tool. In my view, the earliest reception of a New Testament book, although there may be only a few witnesses for this reception, is of capital importance. I have suggested to a doctoral student the idea of writing a dissertation about the Gospel of Luke in the second century: extending the Lukan trajectory into this period and asking who was

\footnotetext{
${ }^{78} \mathrm{Karl}$ Erlemann, Das Bild Gottes in den synoptischen Gleichnissen (BWANT 126; Stuttgart: Kohlhammer, 1988).

${ }^{79}$ David P. Moessner, Lord of the Banquet: The Literary and Theological Significance of the Lukan Travel Narrative (Minneapolis: Fortress, 1989) 290.
} 
interested in Luke. Why did the Gnostics use an allegorical method of interpretation for a document that seems to us to be historically rather than metaphorically oriented? What form of the text did Marcion have at his disposal? Did he also use some of the written sources of Luke, for example, the source of Luke's special materials or an earlier form of the Gospel (Proto-Luke)? Was Marcion the only one who corrected the text of Luke? Marcion accused the catholics of doing as much, and Tertullian does not refute this criticism. What kind of influence did the Gospel of Luke have on apocryphal texts, such as the Protevangelium of James, the Infancy Gospel of Thomas, the Apocalypse of Peter, or the Gospel of Thomas? What can be said about the most ancient witnesses to the direct textual transmission: the title, the presentation, and the text of the oldest extant copies on papyrus, especially $\mathfrak{P}^{75}$ (Papyrus Bodmer XIV-XV)? At the date of the writing of this papyrus (ca. $225 \mathrm{CE}$ ), the Gospel of Luke was already detached from the Acts of the Apostles, and the latter was transmitted separately. Luke is no longer an "author": he has become one of the evangelists. His work is no longer a piece of historical literature written and distributed for private profit; it has become sacred scripture for ecclesiastical edification.

The oldest extant notices about the evangelist are also noteworthy, regardless of their historical value. The Muratorian Canon gives the name "Luke" to the author-a name that never occurs in the text of the work itself-and describes him as a fellow worker of the apostle Paul. Unfortunately, we do not possess a testimony of Bishop Papias of Hierapolis; but we do have the witness of Irenaeus, as well as the so-called Antimarcionite Prologue, the first part of which may have been written at the end of the second century. ${ }^{80}$

Not much more can be said at this stage, because most of the preceding questions have not yet been sufficiently investigated. Such an investigation is vital, however, because the enigmatic second-century life of the texts that later became incorporated into the New Testament is relevant for understanding the texts themselves in their historical matrix. Historical method has taught us to look for themes that existed prior to the writing of the Gospel and that may have extended a literary influence. Other scholars, working exclusively with the preserved text, have been dismantling and rebuilding the structure and ideological economy. It is also necessary, however, to appreciate this Gospel as it was read in the second century and to allow this understanding to illuminate what the text could have been in its original state.

${ }^{80}$ Koester, Ancient Christian Gospels, 334-36; Bovon, L'Evangile selon saint Luc, 27-29. 


\section{Conclusion}

First of all, it seems a relatively easy task to enumerate the fields of research and to circumscribe the relevant duties of each discipline. I am in good company when I advocate a multiplicity of approaches. In view of the diversity of the methods of inquiry, however, it is more difficult to take the next step necessary: to find the intellectual strength to coordinate the several fields of inquiry.

The following example may serve to illustrate my hopes for the direction of future research. The Birth of the Codex, written by two librarians, Colin H. Roberts and T. C. Skeat, is in my opinion a theological work. ${ }^{81}$ Through firsthand information about the origin of the codex and through codicological insights, it brings to light the social world and the beliefs of the Alexandrian Christians at the turn of the third century. Such an endeavor truly provides a fresh understanding and marks a notable advance in the field of theology.

It is necessary to overcome exclusivistic methods. Interest in the structure of Luke-Acts and in rules of literary composition are not incompatible with the historical perspective. Indeed, literary devices that try to uncover the overall structure of an ancient work must be situated at a specific time and in a particular society. There may be universally valid laws for the telling of a story, but it is still necessary to know the local habits of Greeks and Jews in the period of late antiquity. An analogous request can be made to historians and philologists. Because of the nature of the biblical texts, historical and philological work that is done in hermetic isolation from religion and theology will result in a misunderstanding of the Gospel and its message.

My second comment is a request that $I$ address to myself as well as to teachers and scholars whom I know. The level of philological sophistication, as far as I can judge, is usually excellent in the interpretation of the Hebrew Bible, but there are too many commentators of the New Testament who fall short of this same level of philological expertise. Some may be interested only in the study of sources, others give attention only to literary structure; if one adds to this the general decline of learning in the disciplines of the classical humanities, one can well understand the reasons for the existing deficiencies in philology.

Discussions with my friend Bertrand Bouvier, the professor of modern Greek in the University of Geneva, have given me a new sensitivity for the biblical language of the New Testament. If one devotes close and sensitive

\footnotetext{
${ }^{81}$ Colin H. Roberts and T. C. Skeat, The Birth of the Codex (The British Academy; London/New York: Oxford University Press, 1983).
} 
attention to each word, the word becomes alive and shines brightly. In

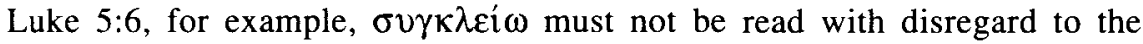
preposition oúv: the composite verb describes a circular movement by which

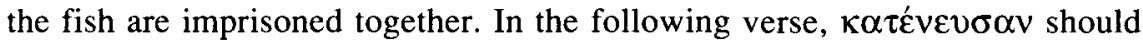
not be translated "they called" to those in another boat to help, as in some

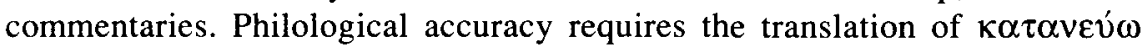
with "to make signs." These observations lead to the conclusion that the Lukan text describes a traditional way of fishing in the ancient world ${ }^{82}$

Interest in the small details is not dictated by the belief that small is beautiful, but by the conviction that through concrete and specific cultural or social realities one can learn about the general and universal structures of human life. Is it not said in the biblical tradition that spiritual life is bound to historical events, and that universal salvation comes through the election of particular people-Israel, Christ Jesus, and Christian fellowship?

My third and last comment here concerns the theological orientation of Luke. In my opinion, the evangelist's vital preoccupation is to give shape to the memory of Jesus and to capture and confirm in words the remembrance of his deeds and sayings. However aesthetically pleasing the result of the work of his pen may be, his artistic shaping of the tradition corresponds to a necessity of his faith, namely, to give written support to the oral teaching and preaching. Otherwise the message would raise hopes without assuring confidence and continuity, and the gospel message might be caused to stumble in the face of Jewish and pagan opposition that wanted to disfigure Jesus' intentions and actions. Luke is certain that the ministry of Jesus is nothing less than the final word of God, the fulfillment of prophecies and the anticipation of the last events. He is fully convinced that the coming of Jesus is the decisive and final step in the history of God with his people. The words of Jesus the Lord are for Luke the source of life; Jesus' fate, death, resurrection, and ascension are the prelude to the last days. Beginning with those events, the recapitulation of the course of Jesus' ministry, the proclamation of the word, the manifestation of the spirit, and the practice of the double commandment of love are the great things that must be told. This is exactly what Luke endeavors to tell in the Book of Acts, while remembering that this movement into the future is not yet triumphant.

${ }^{82}$ Bovon, L'Evangile selon saint Luc, 226-27. 


\section{Appendix}

I would add a few comments on the most significant book in the study of the structure of Luke, namely, that of Jean-Noël Aletti. ${ }^{83}$ A Christian exegete who is interested in theology and history, this Roman Catholic professor discloses the narratological dimension of the gospel text. In his analysis of biblical stories he is interested in the forms that specific content takes, and he tries to discover the narrative techniques of the author, in this case, Luke. Attentive to the characters-the protagonists and their relations-and to the way in which they are described, he looks at their movements and actions. In the episode of Zacchaeus, for example, Aletti notices that the initiative belongs to Jesus, who invites himself to the meal with the publicly acknowledged sinner, whose repentance is not even mentioned. Nevertheless, Zacchaeus is the protagonist, that is, the person who undergoes an internal transformation. At this point, Aletti observes that the narrator introduces the subject matter in a neutral and detached manner, leaving to the characters themselves the responsibility to express affections and feelings and to reveal the bottom of their hearts, their misery, and their repentance. In addition to the analysis of space and time of the narrative, the narratologist Jesuit scholar investigates the plot, an operation that gives him the opportunity of quoting other pericopes of the Gospel (by analepsis Luke 19:1-10 takes over and develops the topic of Luke 15:1-7, the lost sheep; the topic is articulated in Luke 18:35-43 through the motif of sight) as well as of the Bible as a whole (by using intertextuality he sees that Luke 19:1-10 is nourished by Ezekiel 34, the shepherds of Israel). Such inquiries help Aletti to detect-and this is for me the most valuable aspect-the point of view and the perspective of the narrator, namely, what the author puts in perspective, why and how he works, what he likes to underline or to omit, in short, his art, intuitions, convictions, and intentions. Aletti's work is important. It gives an analysis of the most significant passages of the Gospel of Luke, particularly of the special materials of this Gospel.

${ }^{83} \mathrm{Aletti,}$ L'art de raconter Jésus-Christ. Space does not allow me to give justice to Charles L'Eplattenier, Lecture de l'évangile Luc (Paris: Desclée, 1982). It is also important to mention David L. Barr and Judith L. Wentling. "The Conventions of Classical Biography and the Genre of Luke-Acts: A Preliminary Study," in Charles H. Talbert, ed., Luke-Acts: New Perspectives from the Society of Biblical Literature (New York: Crossroad, 1984) 63-88. 